\title{
Cultural Heritage and Sustainable Taxation - empowering communities in the COVID-19 times
}

\author{
RICARDO GARCÍA ANTÓN \\ Assistant Professor of Tax Economics at Tilburg University (Fiscal Institute Tilburg) and \\ former Associate Researcher at the IBFD \\ R.GarciaAnton@tilburguniversity.edu \\ https://orcid.org/ 0000-0002-0823-3170
}

\begin{abstract}
This paper examines how Italy's case law has dealt with work-related diseases (e.g. acoustic neuroma and parotid gland tumour) caused by cell phone use. In order to award workers sickness benefits, case law has ruled that some degree of probability might be sufficient to establish the causeand-effect relationship between exposure to some risks and the development of a disease. In the authors' view, this aspect confirms that labour laws fail to keep up with the new risks linked to technological innovation, especially in relation to new work environments, co-working areas e remote work. In order to deal with this issue, a starting point could be promoting interdisciplinary cooperation between scientific research, administration bodies and legal sciences.
\end{abstract}

Keywords: COVID-19, cultural heritage, re-designing tax policy, community.

Summary: 1. INTRODUCTION. 2. SHORTCOMINGS FROM A TOP-DOWN APPROACH TO PRESERVE CULTURAL HERITAGE. 2.1. Tax benefits on sponsorship. 2.2. Tax incentives on private owner of cultural heritage sites. 2.2.A. Tax allowances. 2.2.B. Tax credits. 2.2.C. Exemptions in wealth, capital gain, inheritance and property taxes. 2.3. Tourist taxes. 2.4. An unsatisfactory statist dimension to protect our cultural heritage. 3. COVID-19 AS THE BASIS FOR A COMMUNITY-BASED APPROACH: TAX MEASURES FOR CULTURAL HERITAGE COOPERATIVES. 4. A NEW INTERPRETATION OF "INCENTIVE MEASURES" UNDER ART. 167 (5) TFEU. 5. CONCLUSIONS. 6. BIBLIOGRAPHY. 


\section{INTRODUCTION}

In the EU countries, protecting our cultural heritage ${ }^{1}$ undergoes a looming challenge, namely the financial constraints derived from the lack of public resources ${ }^{2}$. Due to the previous financial crisis (2008-2010) and the upcoming economic crisis derived from the COVID-19 pandemic, it more obvious that private engagement in cultural heritage needs to be stimulated by the States ${ }^{3}$. However, this art. poses the following research question: is the current tax regime designed to foster private engagement sustainable in a long-term?

In this art., this author will argue that the current tax measures, which are divided in three main clusters (private sponsorship, incentives to private owners of cultural sites and tourist taxes), follow a State dimension, a sort of "top-down" approach. Putting bluntly, the State pinpoints what needs to be preserved and only few stakeholders are the recipients from the tax measures. To challenge this previous top-down vision, this author would plead for creating tax measures that endorse a community-centred approach.

The role of the communities in preserving cultural heritage is not new in the literature on economics of cultural heritage ${ }^{4}$. The recent involvement of private sector in the preservation of cultural heritage raises awareness of the value of cultural heritage in our democratic societies, which cannot be exclusively allocated to the public administration. Preserving cultural heritage is a collective task of our democratic societies. Therefore, not only the decision-making but also the allocation of economic resources must be shared by these three actors: public sector authorities, non-market actors (consumers, neighbors, associations, NGOs, civil societies) and market actors (private entrepreneurs). In this line, SEAMAN avoids facile designations of heritage sites as pure public goods that require only public sector solutions ${ }^{5}$. An example brought by this author is the preservation of the "Fabulous Fox Theatre" (Atlanta, US) in which

\footnotetext{
${ }^{1}$ In this contribution, we refer to cultural heritage as tangible heritage (buildings, museums, works of art, cultural and archeological sites, etc.), thereby carving out intangible heritage.

${ }^{2}$ See BENHAMOU, F., "Public Intervention for Cultural Heritage: normative issues and tools", in RIZZO, I. \& MIGNOSA, A. (eds), Handbook on the Economics of Cultural Heritage, Elgar, 2013, p. 14. As an example, in Spain during the period 2008 - 2017, the State investment in protecting and preserving our cultural heritage has plummeted 70\%. See these data in El Pais, 11 April 2017, http://cultura.elpais.com/cultura/2017/04/04/actualidad/1491291998_103518.html.

${ }^{3}$ In this regard, see MASTELLONE, P., "International and EU Measures for the Protection of Cultural Heritage: Towards Broader Use of Tax Breaks to Stimulate Private Engagement', European Taxation, IBFD, vol. 59, n. ${ }^{\circ}$ 2/3, pp. $81-88$.

${ }^{4}$ PHILLIPS, R.G. and STEIN, J.M., “An Indicator Framework for Linking Historic Preservation and Community Economic Development", Social Indicator Research, vol. 113, n. ${ }^{\circ}$ 1, 2013, pp. 1-15; ATECA AMESTOY, V. "Demand for cultural heritage", in RIZZO, I. \& MIGNOSA, A. (eds), Handbook on the Economics of Cultural Heritage, supra note 2, pp. 89-110; SEAMAN, B.A., "The role of the private sector in cultural heritage", in RIZZO, I. \& MIGNOSA, A. (eds), Handbook on the Economics of Cultural Heritage, supra note 2, pp. $111-128$.
}

${ }^{5}$ SEAMAN, B., supra note 4, p. 111. 
citizen activism and non-profit fundraising trigger the reaction of the Atlanta municipality to deny a private company the demolition permit of this historical building.

Rather than conceiving cultural heritage in a passive way as a duty to preserve imposed upon the public authorities, the 1972 UNESCO World Heritage Convention ("1972 UNESCO") heralded that everyone has the right to enjoy culture and decides which cultural heritage should be preserved. Community-approach should definitely pervade in the field of taxation and complement the current tax policy design. As this author will argue, COVID-19 may be the right trigger to rethink tax policies from a community perspective. In that sense, cultural heritage offers an excellent field research to experience this new approach. Finally, this author will argue that this community-centred tax regime can be potentially enforced at the EU level, through a re- interpretation of art. 167 (5) TFEU.

The structure of this contribution is as follows. Section II is devoted to present the shortcomings of the current tax measures designed to preserve cultural heritage from a top-down approach. In Section III, this author will make the argument why COVID-19 is the right trigger to push towards a community-centred approach in the design of tax policies, namely on cultural heritage. Finally, Section IV sketches a proposal of a regime to preserve cultural heritage under a community-centred dimension, thereby wondering whether the EU should step in.

\section{SHORTCOMINGS FROM A TOP-DOWN APPROACH TO PRESERVE CULTURAL HERITAGE}

The majority of EU countries neglect the role of the community and individuals in the preservation of cultural heritage. As such, culture appears to be narrowed down to the mandate of public authorities to preserve the cultural heritage sites. For example, art. 9 of the Italian Constitution states that: "The Republic promotes the development of culture and of scientific and technical research. It safeguards natural landscape and the historical and artistic heritage of the Nation". Art. 22 of the Dutch Constitution reinforces the Statist dimension to preserve cultural heritage, "the authorities shall promote social and cultural development and leisure activities". Art. 5 of the Polish Constitution declares that:" The Republic of Poland shall safeguard the independence and integrity of its territory and ensure the freedoms and rights of persons and citizens, the security of the citizens, safeguard the national heritage and shall ensure the protection of the natural environment pursuant to the principles of sustainable development". Art. 46 of the Spanish Constitution states that "The public authorities shall guarantee the preservation and promote the enrichment of the historical, cultural and artistic 
heritage of the peoples of Spain and of the property of which it consists, regardless of their legal status and their ownership. The criminal law shall punish any offences against this heritage" 6 .

Such as Statist dimension of cultural heritage influences tax law. In terms of tax policy, the States traditionally follow two paths to preserve cultural heritage. First, the States boost the private sector's involvement in preserving our cultural heritage (Sub-Section II.1. and II.2). Second, the States combat the harmful effects of mass tourism in our cultural heritage sites by levying "tourist taxes" (Sub-Section II.3).

\subsection{Tax benefits on sponsorship}

Provided that sponsorship means financial support of our cultural heritage assets from private actors, this philanthropic engagement of the modern societies with the preservation of our cultural heritage applies to two categories of taxpayers: (i) the recipient of the financial support (the non-profit institutions performing the functions of preserving the cultural heritage); (ii) the donors (the sponsors).

The budgetary difficulties led the governments to rely on the active engagement of certain nonprofit institutions such as NGOs, foundations, associations, museums, etc. to preserve the cultural heritage ${ }^{7}$. In some countries, particular non-profit institutions such as museums are exempt from Corporate Income Tax (Japan, US) ${ }^{8}$. In relation to the taxation of charities, Gliksberg points out that States may opt between a full exemption model (Australia, Ireland and Hungary ${ }^{9}$ ) and partial exemption model in which only the non-business income is taxed (the vast majority of countries adopts this model) ${ }^{10}$.

The partial exemption regime yields certain misleading effects. In Spain, for instance, art. 2 of Law 49/2002 designs a partial exemption regime for a closed list of non-profit organizations dully registered (foundations, associations formally declared in the public interest, other non-

\footnotetext{
${ }^{6}$ The duty of the State to preserve the cultural heritage could also be found in art. 11 bis of the Luxembourgish Constitution; art. 8 and 9 of the Maltese Constitution; art. 9 (e) of the Portuguese Constitution; Art. 17 of the Finnish Constitution; Art. 44 of the Slovak Constitution.

${ }^{7}$ There is abundant literature on the taxation of non-profit organizations. See among others, IFA, Cahiers de Droit Fiscal International, 53 ${ }^{\text {rd }}$ Congress of IFA, (Kluwer, 1999); BATER, P. et al., The Tax Treatment of NGOs, (Kluwer, 2004); KOELE, I.A., International Taxation of Philanthropy, IBFD, 2007; BOWLER-SMITH, M. et al. (eds.), Taxation of charities: EATLP Annual Congress Rotterdam 31 May - 2 June 2012, IBFD, 2015.

${ }^{8}$ See HEMELS, S, “Tax Incentives as a Creative Industries Policy Instrument”, in HEMELS, S. \& GOTO, K. (ed.), Tax Incentives for the Creative Industries, Springer, 2017, p. 39.

${ }^{9}$ In Europe, Hungary, Cyprus, Netherlands, Ireland, Latvia, Malta and Poland provide for full exemption regimes, See HEIDENBAUER, S., Chariting Crossing Borders, Kluwer, 2011, p. 12.

${ }^{10}$ GLIKSBERG, D., “General Report”, IFA Cahiers de Droit Fiscal International, supra note 7, p. 38.
} 
profit organizations with the former legal structure, the Catholic Church, etc. $)^{11}$. Not only donations, fees from the members and subsidies are exempted, but also income derived from the economic exploitation of cultural heritage assets provided that they are open to the public and comply with the substantive regulation of this kind of cultural asset ${ }^{12}$. However, two serious concerns arise regarding this restrictive partial exemption in Corporate Income Tax ${ }^{13}$ :

- First, the scope is limited to cultural assets according to the regulation of the Historic Heritage of the State and the Regions, which also comply with the substantive regulations regarding the public exposure of the assets. The State, and in Spain, also the Regions, decide the tangible and intangible cultural heritage that deserve protection and therefore can be the recipients of tax benefits. Non-listed assets are not covered and thus deprived of tax incentives. Intangible cultural assets are more difficult to be recognized and thus included in the list, since the criteria could be more diffuse than those applied to tangible goods ${ }^{14}$. As an example, in 2019, the Spanish Government declared the manual ringing of bells and the esparto culture as "Representative Manifestations of the Intangible". The criteria to do so are definitely more subjective than the recognition of a castle from the XVI century, for example. The recourse to a closed list of tangible and intangible cultural heritage renders extremely difficult to protect cultural heritage in countries like Spain or Italy with a huge heritage, without cannot be simply reduced to a closed list of items.

- Second, since Law 49/2002 taxes economic activity beyond the social purpose, it carves out from the exemption benefits which are obtained from economic activities out of the social purpose, but are addressed to funding the non-profit activities. For example, in the author's view, it would be taxed the income derived from renting an old castle listed under the Historic Cultural Heritage Catalogue for private celebrations/parties, although the proceeds are spent to make some urgent renovation works of the castle. Only the income derived from the tourist's visits would be exempted. The partial exemption regime has a quite narrow scope and leaving aside economic activities beyond the social purpose - restrictively interpreted - may jeopardize the final goal that is the preservation and conservation of the cultural heritage.

With regard to the tax treatment of the sponsors, in the majority of countries, the donors (individuals, entrepreneurs, companies, etc.), who economically support activities of preservation and conservation of culture heritage goods by making donations, enjoy tax

\footnotetext{
${ }^{11}$ See art. 3 of the Spanish Law 49/2002 on the substance, i.e. $70 \%$ of the income shall target cultural activities and formal requirements to be granted the special tax regime.

12 See art. 7 (4) of the Spanish Law 49/2002.

${ }^{13}$ On a critical view of this regulation, see BÁEZ, A. \& PEDREIRA, J., "Spain”, in Taxation of charities: EATLP Annual Congress Rotterdam 31 May - 2 June 2012, supra note 7, pp. 511 - 540.

${ }^{14}$ In Spain, recently, Law 10/2015, 26 May granted protection to the intangible cultural heritage and laid down the procedure to include this intangible cultural heritage within the list of protected goods ("Representative Manifestations of the Intangible cultural heritage").
} 
deductions in their Individual/Corporate Income Tax. In Spain, the tax credit applied to such donations is restricted to the non-profitable organizations and certain public entities. In Italy, the art bonus regime grants a $65 \%$ tax credit to individuals, non-profit organizations and companies making charitable donations in support of the restoration and maintenance of public cultural goods (for example, monuments, historical buildings, works of art, etc.), public cultural institutions (for example, museums, libraries, archives, archaeological areas, parks), etc ${ }^{15}$. The financial sponsorship is really relevant in some countries like in USA, wherein $38 \%$ of budget from museums comes from donors in the private sector (individuals, charities and corporations), and only $24 \%$ from direct government support ${ }^{16}$. In terms of tax benefits: "a total of $80 \%$ of high-income countries offer incentives to both corporate and individuals donors. Twenty-eight countries (16\%) offer tax incentives to corporate donors but not to individual donors" $" 17$.

Taking the example of Spain, law 49/2002 opts for a tax credit for any kind of donation made in favor of the entities listed in this law. In the literature, some authors argue that it would be convenient to grant a different treatment based on the aim pursued by the donor ${ }^{18}$. As such, donations aiming to benefit the economic activities of the donor ("marketing purposes") should be distinguished from pure philanthropic donations. In the author's view, due to the difficulties to prove the intention of the donor, the regime is unlikely to be implemented in practice.

Law 49/2002 draws a distinction between a donor who is a natural person and a resident company. For natural persons, the art. 19 Law 49/2002 does not allow for a carry-forward in case the credit cannot be used. Conversely for resident companies, a carry-forward of 10 years for the tax credit is provided ${ }^{19}$. Instead of tax credits, in some countries like Germany, donations are deductible from the taxpayer's tax base at an amount up to $20 \%$ of total income ${ }^{20}$.

\footnotetext{
${ }^{15}$ On a detailed analysis of this tax credit, see MUCCIARIELLO, A., "Art bonus e crowdfunding”, in CORDEIRO GUERRA, R., PACE, A. VERRIGNI, C. and VIOTTO, A. (eds), Finanza pubblica e misure tributarie per il patrimonio culturale. Prime riflessioni, Giappichelli, 2019, pp. 265 - 280; MASTELLONE, P., supra note 3, Section 3.4.1.

16 HEMELS, S., "Tax Incentives for Museums and Cultural Heritage", HEMELS, S. \& GOTO, K. (ed.), Tax Incentives for the Creative Industries, Springer, 2017, p.109.

17 HEMELS, S., supra note 16, p. 110.

${ }^{18}$ On this view, see SUÁREZ-INCLÁN, M.R., "Financial Regulations and Tax Incentives with the Aim to Stimulate the Protection and Preservation of cultural Heritage", in B. HOFFMAN (ed), Art and Cultural Heritage: law, policy and practice, Cambridge Univ. Press, 2006, p. 459.

${ }^{19}$ On the potential discriminatory treatment, see BÁEZ, A. \& PEDREIRA, J., supra note 13, p. 529.

${ }^{20}$ JOCHUM, H. \& LAMPERT, S., "Germany”, in Taxation of charities: EATLP Annual Congress Rotterdam 31 May - 2 June 2012, p. 298.
} 


\subsection{Tax incentives on private owner of cultural heritage sites}

Many cultural heritage assets/sites are privately owned (i.e., $44 \%$ of buildings in UK, 35\% for listed buildings in France) $)^{21}$. For the Council of Europe (2003) $65 \%$ of cultural heritage sites and buildings in Europe are under private property rights ${ }^{22}$. The conflicts between private owners and the need to preserve the public interest are indeed quite frequent. In the words of the Council of Europe (2005), "The relevant question for this report is how to ensure that cultural property is properly maintained. On the one hand there is need for assessment of the cultural or historical importance of the property (for example by listing or inventory). Owners can be expected to take reasonable measures to maintain and protect significant property. On the other hand the rights of property ownership should be respected (including the commercial exploitation of a property as hotel or guest house). A balance must be found, but one which ensures that the cultural heritage is protected".

The majority of countries encourage protection of the cultural heritage by granting wide tax breaks, tax relief, tax aids, tax rebates, generally dubbed tax incentives ${ }^{23}$. These tax incentives target private owners of these cultural heritage sites. In these countries, this system of tax incentives is also connected to a classification of buildings that have a cultural and historic interest. Listing a building as an historic monument precludes the owner to alter the property and introduce strong constraints on the legal ownership. Consequently, the States must compensate the owners by granting them abundant tax rebates: deductions on conservations expenses, exemptions in local wealth and capital gain taxes, favorable treatment in Inheritance tax, reduced VAT on construction and repair works on historical buildings ${ }^{24}$, etc.

Striking a proper balance between the citizens' right to get a full enjoyment of public cultural goods and opening the floodgates for private actors is not easy. In other words, "two sources of tensions may emerge: between protection and openness, and between the scope of private property and the recognition that the property of a listed building is de facto shared between the

${ }^{21}$ BENHAMOU, F., "Who owns cultural goods? The case of built heritage", in GINSBURGH, V.A. (ed), Economics of Art and Culture, Elsevier, 2003, pp. 187 - 202. Also available at: ftp://mse.univparis1.fr/pub/mse/cahiers2003/R03102.pdf. See also THE COUNCIL OF EUROPE, The private management of cultural property, 24 October 2005, Report 10731, available at: http://assembly.coe.int/nw/xml/XRef/X2H-XrefViewHTML.asp?FileID=11062\&lang=.

22 THE COUNCIL OF EUROPE, Tax incentives for cultural Heritage Conservation, 13 November 2003, Report 9913, available at: https://assembly.coe.int/nw/xml/XRef/X2H-Xref-ViewHTML.asp?FileID=10311\&lang=en

${ }^{23}$ On the definition of tax incentives, see HEMELS, S., supra note 8, p. 35.

${ }^{24}$ On VAT, several countries (Belgium, France, Ireland and Italy) apply lower VAT rates on dwelling renovation and repair works than those rates tend to apply to new constructions. In other Member States, repair works on historical buildings are charged at a lower VAT rates. See REVELLI, F., "Tax Incentives for Cultural Heritage Conservation", in RIZZO, I. \& MIGNOSA, A. (eds), Handbook on the Economics of Cultural Heritage, Elgar, 2013, p. 137. 
private owner and the collectivity" ${ }^{\prime 25}$. Whereas in Greece and Spain, the private owners of these private cultural assets suffer strict legal limitations on their rights to enjoy their assets, in the Anglo-Saxons countries, entrepreneurial solutions are mostly encouraged so the scope of the owner's right to property are not curtailed in excess. Although private sector must collaborate to guarantee the cultural heritage protection, the model of cooperation cannot neglect that public intervention is always necessary to enable the peoples to access the national cultural heritage ${ }^{26}$. In the next sub-sections, based on HEMELS's wide range classification of this kind of tax incentives $^{27}$, this author briefly describes its main features.

\subsection{A. Tax allowances}

Allowances are deductions from the tax base in Income and Wealth Taxes: "the owner may deduct specified expenditures on conservation or restoration from income, reducing effective taxable income" 28 . As REVELLI notices, in most countries, "expenditures are deductible up to a limit, and depending on whether the building is owner-occupied or rented, and it is open or not to the public" 29 . In Netherlands, for example, individuals owning a registered building of historical interest could deduct $80 \%$ of certain maintenance and restoration costs from their taxable income $\mathrm{e}^{30}$.

\subsection{B. Tax credits}

Some countries opt for a tax credit, which does not reduce the tax base, but entitles the owner to deduct a fixed percentage of those expenditures incurred in the restoration or conservation of the historical building. In Europe these deductions usually go between 15\%-20\% of the expenditure incurred in the reparation.

In Spain, for instance, art. 68.5 LIRPF states a 15\% deduction (limited to $10 \%$ of the tax quota) on the expenses incurred by the taxpayer on the acquisition, restoration and conservation on

\footnotetext{
${ }^{25}$ BENHAMOU, F., "Public Intervention for Cultural Heritage: normative issues and tools", in RIZZO, I. \& MIGNOSA, A., Handbook on the Economics of Cultural Heritage, Elgar, 2013, p. 6.

${ }^{26}$ HOLLER, M.J. \& I. MAZZA, I., “Cultural heritage: public decision-making and implementation”, p. 31; KLAMER, A., MIGNOSA, A. \& PETROVA, L., Cultural Heritage policies: a comparative perspective, p. 41. In the field of Cultural Economics, the intervention of the public sector is necessary to solve positive externalities (market failures whenever the actions of a party make another party worse or better off). This occurs when the owner of a historical monument has to bear with the costs of its maintenance although the collectivity benefit from its restoration. Although externalities could justify public interventions, not all government interventions can be rationalized on the basis of economic theory. See on the concept of externalities, GOTO, K., "Why do Governments Financially Support the Creative Industry", in HEMELS, S. \& GOTO, K. (ed.), Tax Incentives for the Creative Industry, Springer, 2017, p. 25.
}

${ }^{27}$ HEMELS, S., supra note 8, p. 39.

${ }^{28}$ REVELLI, F., supra note 24, p. 136.

${ }^{29}$ REVELLI, F., supra note 24, p. 137.

${ }^{30}$ HEMELS, S., supra note 16, p. 131. 
cultural heritage assets which are listed either at UNESCO or at national level or at regional level. For entities subject to corporate income tax, this deduction was repealed in 2014. The fact that the deduction only applies to cultural assets listed in three above-mentioned list excludes cultural heritage goods included in local lists elaborated by city councils ${ }^{31}$. This deduction applies to the acquisition of cultural heritage goods abroad, provided that the taxpayer keeps the goods at his disposal in Spain for at least 4 years.

\subsection{Exemptions in wealth, capital gain, inheritance and property taxes}

Some countries introduce tax exemptions in property, wealth and capital gain taxes if the monuments are listed: "in most European countries - including Denmark, Germany, Italy, Spain and the UK - Historical properties are either exempt altogether or very lightly burdened by local property taxes, irrespective of investment conservation" 32 .

Art. 4 of the Spanish Wealth Tax grants an exemption for cultural heritage assets listed either at national or regional level. Likewise, in Spain, art. 62.2 b) of the Consolidated Law regulating Local Finances for properties expressly grants an exemption on the real estate tax ("IBI") for particular assets listed. As Casas Agudo argued, the fact that the exemption applied to a particular type of listed cultural assets yielded inconsistencies and casuistic disputes continuously arising at Spanish courts and tribunals ${ }^{33}$. The Law 16/2012 introduced new paragraphs in art. 74 of the Consolidated Law regulating Local Finances to grant tax rebates to cultural heritage goods which are not covered by $62.2 \mathrm{~b}$ ) provided that the city halls approve them in their local norms ('Ordenanzas Locales').

In relation to Inheritance tax, countries like UK, France, the Netherlands, Ireland, Italy, Belgium and Spain have introduced an option to pay inheritance tax by transferring such cultural heritage to the State ("acceptance in lieu of tax"). Consequently, this incentive prevents the heirs to sell the cultural heritage before the owner dies.

\subsection{Tourist taxes}

There is a clear bond between heritage and tourism industry. Mass tourism is becoming unfortunately more frequent in our European cities, leading to destructive impacts on our societies, culture and environment. The existing literature is aware of the need to design a more sustainable mass tourism ${ }^{34}$. Tourists benefit from public goods at zero-cost and in compensation

\footnotetext{
${ }^{31}$ See Spanish Tax General Directorate, Ruling on 21.02.2012.

${ }^{32}$ REVELLI, F., supra note 24, p. 136.

${ }^{33}$ See further analysis, including case law by Spanish courts, in CASAS AGUDO, D., "Patrimonio histórico y extrafiscalidad en el ámbito de la Hacienda Municipal”, Revista española de Derecho Financiero, núm. 172/2016.

${ }^{34}$ On the need to build up a sustainable to prevent the risks associated to mass tourism, see for example PEETERS, P. "A clear path towards sustainable mass tourism? Rejoinder to the paper 'Organic, incremental and induced
} 
the economic returns from tourism are indirect (tourism support services) ${ }^{35}$. To prevent that mass tourism could spoil and damage our cultural heritage, tourist taxes are enacted. In a certain way, they constitute the direct economic return from the tourists' enjoyment of free public goods. Introducing tourist taxes poses a difficult equilibrium between the need to preserve our cultural heritage from harmful effects of mass tourism, and the need to foster the local economies $^{36}$. Tourist taxes should be proportional because higher tourist taxes would make the tourists simply find a cheaper destination ${ }^{37}$.

The IBFD Glossary defines tourist taxes as: "Taxation of tourists is generally restricted to a service charge or airport tax levied when the tourist leaves the country by air, but indirect taxation in the form of a room tax or a hotel and restaurant tax may be applied to the class of hotels and restaurants commonly used by tourists so that the tax falls mainly on them" 38 . Tourist taxes are generally passed on consumers. Perhaps, it is not always easy to monitor the extrafiscal purpose of these tourist taxes to preserve the historical sites. For instance, in April 2017, Malaysia passed the Tourism Tax bill, which will be imposed and levied on tourists staying at any accommodation made available by any operator39. In Spain, Cataluña and Islas Baleares have passed tourist taxes destined to finance the tourism sector ("Fondo para el Fomento del Turismo") without express mention to the cultural heritage. Conversely, In Italy, the proceeds obtained from the tourist taxes ("Imposta di soggiorno") are clearly destined to fund the conservation and preservation of cultural heritage ${ }^{40}$.

\subsection{An unsatisfactory statist dimension to protect our cultural heritage}

The statist dimension on the tax benefits on private sponsorship may raise the following criticisms. First, the State singles out the recipients of the favorable tax regime, namely listed entities in the law (i.e. foundations, associations), as Spanish law 49/2002 did. Second, the partial exemption regime, which is the most common regime applied to these non-for-profit

paths to sustainable mass tourism convergence' by David B. WEAVER", Tourism Management, vol. 33, n. ${ }^{\circ}$, 2012, pp. 1038 - 1041; WEAVER, D.B., 'Organic, incremental and induced paths to sustainable mass tourism convergence', Tourism Management, vol. 33, n. ${ }^{\circ}$ 5, 2012, pp. $1030-1037$

35 ASHWORTH, G., "Heritage and Local Development: a reluctant relationship", in RIZZO, I. \& MIGNOSA, A. (eds), Handbook on the Economics of Cultural Heritage, supra note 2, p. 380.

${ }^{36}$ BONET, L., "Heritage Tourism", in Handbook on the Economics of Cultural Heritage, supra note 2, p. 393.

${ }^{37}$ Studies conducted in Balearic Islands concluded that one euro/tourist tax per day on non-resident tourists would yield a decrease on the demand (117,113 fewer German, British, French and Dutch tourists). See AGUILÓ, E., RIERA, A., ROSSELL, J. "The short-term price effect of a tourist tax through a dynamic demand model. The case of the Balearic Islands", Tourism Management, vol. 26, n. ${ }^{\circ} 3,2005$, pp. $359-365$

${ }^{38}$ See IBFD Glossary, online.

39 See IBFD news, https://online.ibfd.org/kbase/\#topic=doc\&url=/data/tns/docs/html/tns_2017-0407_my_1.html\&WT.z_nav=Navigation.

${ }^{40}$ On further criticisms to tourist taxes in Italy, see BERETTA, G., "L'imposta di soggiorno: amnesie legislative ed esigenze di riforma”, Università Cattaneo working papers, n. ${ }^{\circ}$ 3, 2017. 
entities is not satisfactory on the grounds that: (i) only income derived from the exploitation of cultural heritage sites listed by the State/regional governments/city council is covered, leaving aside non-listed assets; (ii) the partial exemption regime does not apply to income arising for commercial activities addressed to the renovation of the cultural site.

In relation to the tax sponsorship regime (i.e. tax credits) applicable to the donors, the potential relationship between the State and private entrepreneurs is not deprived from ethical issues. There is always a risk that private donors, especially corporations, use the donations given in their own commercial benefit and economic exploitation ("marketing/branding of the cultural sites"). In Italy, the restoration of Rome's Colosseum by Della Valle, which included an agreement to exploit the image of Colosseum for several years sparkled controversy ${ }^{41}$. Likewise, the State rules define what is a cultural site/cultural institution that deserved to be subsidized under the tax credit regime.

With regard to the tax incentives on private owners, the system of listing protected buildings yields to: weigh for public finances, low participation of the citizens on the selection of buildings to be protected (public authorities take the decision), beneficial to a small population (owners of the protected buildings). France restricts itself the number of new building protections per year to avoid excessive burdens on public expenditure ${ }^{42}$. The fairness of the tax system can be jeopardized since tax incentives may infringe the ability to pay principle and are subject to pressures from lobbying groups that make them almost impossible to abolish them (inalienable rights for high income groups who are the owners of these historical buildings) ${ }^{43}$.

In Spain, the 2008-2010 economic crisis triggered the need to increase the collection of local property tax ("IBI"). However, pursuant to Law 16/2012, cultural heritage real estate, which was directly affected to carry out economic activities, was carved out from the IBI exemption. This new amendment requested by the Spanish Federation of Cities targeted hotels such as Palace or Ritz in Madrid ${ }^{44}$. This example shows that tax incentives allocated to the private owners infringe the constitutional ability to pay principle. Inasmuch as these buildings are only enjoyed by few people, there is no reason to keep a general exemption on the property tax. Likewise, the system of listing does not ensure that the buildings are well preserved due to the high costs of rehabilitation and conservation.

\footnotetext{
${ }^{41}$ On the drawbacks of private sponsorship contracts in Italy, see for VENTURA, C., CASSALIA, G. \& DELLA SPINA, L., "New models of Public-private Partnership in Cultural Heritage sector: Sponsorships between models and traps", Procedia Social and Behavioral Science, vol. 223, 2016, pp. 257 - 264.

${ }^{42}$ BENHAMOU, F., supra note 25, p. 10.

${ }^{43}$ HEMELS, S., supra note 8, p. 43.

${ }^{44}$ CASAS AGUDO, D., supra note 33.
} 
Taking as a reference the Spanish situation, the depicted landscape is not very promising. In a nutshell, the State first channels the private engagement in our cultural heritage through nonprofit entities listed in a law (i.e. law 49/2002), second lists the assets that deserves protection and third gives tax breaks to the private owners of cultural assets. And, as a cherry on the top of the cake, tourist taxes, which aim to compensate the harmful effects of mass tourism in our cities, are not always earmarked to preserve our cultural heritage.

\section{COVID-19 AS THE BASIS FOR A COMMUNITY-BASED APPROACH: TAX MEASURES FOR CULTURAL HERITAGE COOPERATIVES}

From a tax policy perspective, once the pandemic passes away, the literature ${ }^{45}$ stresses that the recovery from high public debt levels and the enhancement of our public infrastructures (i.e. public health systems) would be linked to the creation of new taxes (i.e. carbon taxes, excess profit tax or windfall tax ${ }^{46}$ ), increasing tax rates, or narrowing the tax gap. These long-term tax recipes seem inevitable to foster economic recovery and guarantee the resilience of our welfare states seriously hit after a decade of austerity measures and budget stringency.

Apart from these measures, this author would argue that COVID-19 becomes a trigger to foster a community-based approach to taxation. In this sense, BIZIOLI and BERETTA strongly defend the creation of a New Tax Policy Deal, in which individuals and businesses are more accountable for the maintenance of public goods (art monuments, environment, education and health $)^{47}$. Such new Tax Deal based on an idea of solidarity is missing in the current fiscal and tax policy measures enacted in Italy and other countries ${ }^{48}$.

This author completely agrees with the need for a New Deal in taxation as suggested by Bizioli and BERETTA. Such idea of solidarity and belonging to a strong community has been reinforced during the pandemic under the collective need to "flatten the curve" and the compliance with the social distancing measures to protect high segment of population at risk. Such extraordinary solidarity actions handled by the citizens during COVID-19 times have been

\footnotetext{
${ }^{45}$ VAN WEEGHEL, S., "COVID-19 and Beyond”, Intertax, vol. 48, n. ${ }^{\circ}$ 8/9, 2020, p. 735; VAN DENDER, K., O'REILlY, P., \& PERRET, S., "COVID-19 and Fiscal Policies: Tax and Fiscal Policy in Response to the Coronavirus Crisis: Strengthening Confidence and Resilience”, Intertax, vol. 48, n. ${ }^{\circ}$ 8/9, 2020, pp. 736 - 742.

${ }^{46}$ In US, an excess profit tax on corporations that benefit from the pandemic could be enacted. See AVI-YONAH, R., “COVID-19 and US Tax Policy: What Needs to Change?”, Intertax, vol. 48, n. ' 8/9, 2020, pp. 790 - 793; On potential windfall taxes on companies which benefited from the pandemic, see COLLIER, R., PIRLOT, A., VELLA, J., "COVID-19 and Fiscal Policies: Tax Policy and the COVID-19 Crisis", Intertax, vol. 48, n. ${ }^{\circ}$ 8/9, 2020 , pp. $794-804$.

${ }^{47}$ BIZIOLI, G. \& BERETTA, G., "Italy's Tax and Fiscal Policy Measures at the Time of the COVID-19 Crisis: 'Tax Peanuts' Without a New Deal”, Intertax, vol. 48, n. ${ }^{\circ} 8 / 9,2020$, pp. $761-768$.
}

${ }^{48}$ BIZIOLI, G. \& BERETTA, G., supra note 47, p. $767-768$. 
documented in the works of several sociologists ${ }^{49}$. In his latest essay, Zizej also labeled these actions as a new sort of "communism" based on trust in the people ${ }^{50}$. The fact that the communities of citizens are uniting thanks to COVID-19 should be decisive to re-design tax policy under this new lens. Since the preservation of the cultural heritage traditionally respond to Statist approach, which leads to substantial shortcomings as presented in Section 2, why not creating an ad-hoc tax regime for communities in charge of preserving cultural heritage?

Real community engagement in preserving cultural heritage is not new. In 2015, International Centre for the Study of the Preservation and Restoration of Cultural Property (ICCROM) published a report to foster a people-centred approach to cultural heritage ${ }^{51}$. A people-centred approach requires to engage communities in the process of making conservation and management decisions for themselves and their heritage. In other words, an active role of the citizens as holders of cultural rights is needed, rather than a passive constitutional mandate to the public authorities to preserve cultural heritage.

The community approach to cultural heritage has gained strong support, not only within the specialized literature in the field but also in the work of United Nations through programs like "The Community Management of Protected Areas Conservation" (COMPACT) ${ }^{52}$. Such programs articulate eco-friendly and sustainable economic exploitation of cultural sites by the local communities. Such community-centred approach rejects the premise that cultural heritage must be listed in order to be preserved. The community itself must decide which spaces, traditions and goods deserve protection and therefore exploit them on a sustainable way. A recent project called Open Heritage, funded by the European Union's Horizon 2020, is evaluating 6 cooperatives of citizens ("cultural heritage Cooperative labs") to preserve cultural sites over Europe ${ }^{53}$.

Strikingly, this community-run heritage projects are devoid of an ad-hoc legal and tax regime. This is perhaps one of the most serious handicaps of the current regulation which put the stress on non-profit sector and the sponsorship, and therefore neglects that the local communities must

\footnotetext{
${ }^{49}$ SITRIN, M. (ed), Pandemic Solidarity Mutual Aid during the Covid-19 Crisis, Pluto Press, 2020.

50 ŽIŽEK, S., Pandemic!: COVID-19 Shakes the World, OR Book, 2020. On a short overview of the philosophical debate on COVID, see PETERS, M.A., "Philosophy and Pandemic in the Postdigital Era: Foucault, Agamben, Žižek", Postdigital Science and Education, vol. 2, n. . 3, 2020, pp. 556 - 561.

${ }^{51}$ ICCROM, "People-Centred Approaches to the Conservation of Cultural Heritage: Living Heritage" (2015). Available at https://www.iccrom.org/sites/default/files/PCA_Annexe-2.pdf.

${ }^{52}$ BROWN, J. \& HAY-EDIE, T., Engaging Local Communities in the Stewardship of World Heritage, UNESCO, 2014; CHEN, W., HUA, J., 'Citizens' distrust of government and their protest responses in a contingent valuation study of urban heritage trees in Guangzhou (China)", Journal of Environmental Management, n. ${ }^{\circ}$ 155, 2015 , pp. 40 - 48; LI, J., KRISHNAMURTHY, S., RODERS, A.P., VAN WESEMAELA, P., "Community participation in cultural heritage management: A systematic literature review comparing Chinese and international practices", Cities, vol. 96, 2020, pp. 1 -9.

${ }^{53}$ See further information in https://openheritage.eu/oh-project/.
} 
play an important role in preserving our cultural heritage. In the author's view, a proper legal and tax regime to activate local communities and enroll them into the redevelopment of heritage sites should be created from scratch. To borrow the term from the project Open Heritage, cultural heritage cooperatives ("CHC") could be a suitable legal form to articulate such a regime. Indeed, cultural cooperatives may exist in many countries within the favorable regime of cooperative corporations. However, in the author's view, there is a need to link cooperatives with the preservation and sustainable economic exploitation of cultural heritage.

The detailed legal and tax design of the CHC exceeds from the goal of this contribution. However, based on the existing experience in relation to cooperative corporations in EU Member States, few tax guidelines could be sketched:

- Strict rules on the requirements to constitute CHCs, which must exclusively lie in local residents.

- Exemption from transfer and stamp tax in the constitution of CHCs.

- Reduced corporate tax rate (i.e. 5-10\%). As stated in this chapter, the partial exemption regime laid down in many Member States for non-for-profit entities is quite restrictive and does not cover economic activities out of the social object, but addressed to funding the non-profit activities.

- Full relief on local property taxes and surcharges derived from the exploitation of the cultural assets.

- Duty to re-invest a percentage of the profits either in in the activity itself or in the preservation of the cultural site.

In the author's view, the principles leading the cooperative movement ${ }^{54}$ seem to be quite suitable to preserve cultural heritage from a people-centred approach. The previous tax guidelines to set up a specific regime of CHCs aim to kick off the debate.

\section{A NEW INTERPRETATION OF "INCENTIVE MEASURES" UNDER ART. 167 (5) TFEU}

In this section, this author discusses whether a specific regime of $\mathrm{CHCs}$ could be desirable to be fostered at the EU level, thereby answering the question on the EU competence to introduce such a proposal. Pursuant to art. 6 TFEU, the competence in culture is shared between the Union and the Member States. The role of the EU would be limited to support, coordinate and

\footnotetext{
54 In this regard, see the principles of the International Cooperative Alliance in https://www.ica.coop/en/cooperatives/history-cooperative-movement.
} 
supplement the actions of the Member States. Although art. 22 of the Charter of Fundamental Rights states that the Union shall respect cultural diversity, the provisions of the Charter shall not extend in any way the competences of the Union as defined in the Treaties (art. 6 TEU).

Since culture is a shared-competence, art. 167 (2) TFEU affirms that the action of the Union "shall be aimed at encouraging cooperation between Member States and, if necessary, supporting and supplementing their action in the following areas: [...] conservation and safeguarding of cultural heritage of European significance". In case the Union decides to intervene in this area of culture, the requirements of the principle of subsidiarity and proportionality have to be met (art. 5 (3) and 5 (4) TEU). The core competence to preserve of cultural heritage falls within the scope of the Member States. As such, art. 167 (5) TFEU prohibits any harmonization of the laws of the Member States in this field: "the European Parliament and the Council acting in accordance with the ordinary legislative procedure and after consulting the Committee of the Regions, shall adopt incentive measures, excluding any harmonization of the laws and regulations of the Member States"55. In cultural heritage, the Directive 2014/60 on the return of cultural objects which have been unlawfully removed from the territory of a Member State was adopted on the basis of art. 114 TFEU, since it affected the free movement of goods in art. 36 TFEU, and excluded any reference to art. 167 TFEU $^{56}$.

Discarding any approximation of the laws in cultural heritage, the action of the Union would likely fall under the categories of "incentive measures". In terms of taxation and cultural heritage, the Union has simply encouraged the Member States to introduce fiscal incentives in relation to restoration, preservation and conservation work, such as reductions in VAT or other $\operatorname{taxes}^{57}$.

The enactment a potential directive containing the tax regime of CHCs cannot be framed under art.s 114 and 115 TFEU due to the prohibition enshrined in art. 167 (5) TFEU. Moreover, art. 115 TFEU, despite its broad scope ${ }^{58}$, requires that there is an obstruction to the fundamental

\footnotetext{
${ }^{55}$ See for instance on art. 167 TFEU (ex art. 151 EC), see CRAUFURD, R., "Art. 151 EC and European Identity”, in CRAUFURD, R. Culture and European Union Law, Oxford University Press, 2004, pp. 278 - 297.

${ }^{56}$ Directive 2014/60/EU, of 15 May 2014 on the return of cultural objects unlawfully removed from the territory of a Member State and amending Regulation (EU) No 1024/2012 (Recast).

57 See Report of the European Parliament of 24.6.2015, Towards an integrated approach to cultural heritage for Europe (2014/2149(INI)). https://www.europarl.europa.eu/doceo/document/A-8-2015-0207_EN.html.

${ }^{58}$ See Opinion of A.G KOKOTT delivered on 28 January 2016, in Case C-122/15, C, ECLI:EU:C:2016:391, at paragraph 52: "There is hardly any restriction, from the point of view of substance, on the competence enjoyed by the Community or the European Union under that provision. The number of areas of law capable of directly affecting the internal market is incalculably large. Moreover, the determination of whether or not such an effect is present will to a large extent fall within the discretion of the legislature alone. At a procedural level, however, the substantive scope of the competence in matters affecting the internal market as provided for in Art. 94 EC is limited by the requirement of unanimity within the Council".
} 
freedoms or significant distortions of competition ${ }^{59}$. Such direct tax regime applicable CHCs is hardly connected with a genuine improvement of the conditions for the establishment and functioning of the internal market. Rather than preventing obstructions, tax regime of CHCs incentivizes a people-centred approach to cultural heritage. To date, in tax matters, there is no foreseen legislative action in cultural heritage ${ }^{60}$.

The issue is whether a tax regime would fall under "incentive measures" in art. 167 (5) TFEU, bearing in mind first that the competence in the field of direct taxation first lies on the Member States and second, it requires that the principles of subsidiarity and proportionality are met. Pursuant to art. 5 of Protocol (No 2) on the application of the principles of subsidiarity and proportionality, the Union shall give enough reasons why the proposed action can be better achieved at the Union Level by qualitative and quantitative indicators. Such principles, which guide the legislative action of the European Union in case of shared competences, are also subject to judicial review by the CJEU. There is no much explanation in Protocol 2 on the specific criteria, which are broadly left to the impact assessment performed by the Commission $^{61}$. The Protocol (No 2) enhanced the role of the national parliaments in monitoring the compliance of the principles of subsidiarity and proportionality under a strict control mechanism laid down in art. 7 of the Protocol.

Turning to the focus of this sub-section, does the regulation of a tax regime within a potential CHCs at EU level falls under the category of "incentive measure" in art. 167 (5) TFEU? And second, would it comply with the principles of subsidiarity and proportionality? On first sight, the likelihood of an affirmative answer to both questions is quite reduced since the Member States are still competent in direct taxation and, in relation to the subsidiarity principle, the outcome could be better achieved at the national level. The Member States are indeed close to the culture heritage that they want to preserve.

However, this author wishes to soften the previous argument under two premises. First, the principles of subsidiarity and proportionality confer the EU a broad discretion to select the legislative actions to be pursued. Second, a tax regime of CHCs could be included within the wording of "adopt incentive measures" in art. 167 (5) TFEU under a new re-interpretation brought upon COVID-19 times.

- In the case law of the CJEU monitoring subsidiarity pre-Lisbon Treaty, the literature stressed the minimalist approach followed by the Court, which was quite hesitant to interfere with the

\footnotetext{
${ }^{59}$ KOFLER, G., "EU power to tax: Competences in the area of direct taxation", in HJI PANAYI, C. (ed), Research Handbook on European Union Taxation Law, Elgar, 2020, p. 20.

${ }^{60}$ See 5 June 2020, the ECOFIN Report to the European Council on current Tax Issues. Available at https://data.consilium.europa.eu/doc/document/ST-8450-2020-INIT/en/pdf.

${ }^{61}$ KOFLER, G., supra note 59, p. 30.
} 
margin of discretion of the EU legislative institutions ${ }^{62}$. In a post-Lisbon scenario, the new monitoring framework of subsidiarity and proportionality presents a fruitful dialogue between national parliaments and EU institutions, in which the Commission still is bestowed with such broad discretion $^{63}$. The Court has also endorsed the broad discretion of the EU legislative power within the subsidiarity analysis, in "areas in which its action involves political, economic and social choices and in which it is called upon to undertake complex assessments and evaluations" ${ }^{\prime \prime}$. These two premises are still weak and likely to be defeated by the exclusive competence of the Member States in the area of direct taxation.

- In public health, art. 168 (5) TFEU limits the competence of the Union in this domain to "incentive measures", and excludes the possibility for the EU to adopt public health harmonizing measures. Both art.s, 167 (5) and 168 (5) are drafted in a similar fashion. In the need for a Union action in the current pandemic, Alberto Alemanno suggests a new interpretation of "incentive measures" under art. 168 (5) TFEU to implement all the current soft law recommendations of COVID: "Incentive measures would emerge as a novel tertium genus falling in between existing coordination public health measures and prohibited harmonization public health measures" ${ }^{\prime 6}$. Such tertium genus (incentive measures) would enable the EU to step in a competence reserved to the Member States and circumvent the prohibition of harmonization.

Whilst the COVID-19 pandemic pleads for a coordinated Union action to protect the health of all the Europeans, a community-based approach to protect our cultural heritage is also required in dearth of public expenditure. A tax regime on CHCs is a suitable mechanism to be framed under the "incentive measures" in art. 167 (5) TFEU. The subsidiarity principle and the fact that Member States are competent in direct tax matters cannot jeopardize the goal that the peoples decide what and how must be preserved. The competences between the Union and the Member States must respond to the principle of sincere cooperation. As the Editorial Comments of the Common Market Law Review point out: "With subsidiarity comes responsibility. If it becomes an excuse for inaction and/or selfishness, more capabilities should be envisaged at EU

\footnotetext{
${ }^{62}$ On the analysis of the case law of the CJEU pre-Lisbon Treaty, see BIONDI, A., 'Subsidiarity in the Courtroom', in BIONDI, A., EECKHOUT, P. and RIPLEY, S., EU Law after Lisbon, Oxford Univ. Press, 2012, pp. 214-227.

${ }^{63}$ European Commission's Annual Report for 2019 on the application of the subsidiarity and proportionality principle, available at https://ec.europa.eu/info/sites/info/files/com-2020-272-en.pdf.

${ }^{64}$ Case C-482/17, Czech Republic $v$ European Parliament and Council of the European Union, ECLI:EU:C:2019:1035, at paragraph 77; Case C 58/08, Vodafone and Others, EU:C:2010:321, paragraph 52. On a more narrow view of the role of the national parliaments within the subsidiary analysis, see GRANAT, K., The Principle of Subsidiarity and its Enforcement in the EU Legal Order: The Role of National Parliaments in the Early Warning System, Hart Publishing, 2018.

${ }^{65}$ See also ALEMANNO, A., "Testing the Limits of EU Health Emergency Power", VerfBlog, Saturday 18 Apr 2020. Available at https://verfassungsblog.de/testing-the-limits-of-eu-health-emergency-power/.
} 
level, at least if there is still an understanding among Member States that the objectives of the Union are worth pursuing ${ }^{66}$.

In the post-COVID landscape, the power of the Union to legislative would definitely be stretched under the implied powers doctrine (art. 352 TFEU) in the absence of national policy protecting cultural heritage

\section{CONCLUSIONS}

In times of budget stringency, innovative solutions to engage local communities in preserving cultural heritage are needed. COVID-19 becomes an opportunity to enforce such tax policies. In the pandemic, public authorities have been completely overwhelmed by actions taken exclusively at the community level. The current tax measures for the protection of cultural heritage are not fully satisfactory and only few stakeholders benefit from them. Taking the Spanish case, for example, it seems that the private engagement to preserve cultural heritage lies on the non-profit sector and the sponsorship. Real community engagement in preserving cultural heritage, as promoted by UNESCO, does not have a proper specific tax regime.

Under the framework of a New Deal in taxation upon COVID-19, as suggested by Bizioli and BERETTA, it is time to re-design tax policies that stresses the role of the communities. Cultural heritage cannot simply be narrowed down to a mandate public authorities to preserve it, but as the right of the community to fully select, enjoy and preserve our cultural heritage. CHC could be a suitable tax regime to foster such bottom-up approach. Finally, this contribution has supported a broad and innovative interpretation of "incentive measures" laid down in art. 167 (5) TFEU in order to facilitate a legislative action of the Union in this matter.

\section{BIBLIOGRAPHY}

AGUILÓ, E., RIERA, A., ROSSELL, J., "The short-term price effect of a tourist tax through a dynamic demand model. The case of the Balearic Islands", Tourism Management, vol. 26, núm 3., 2005, pp. $359-365$.

ALEMANNO, A., "Testing the Limits of EU Health Emergency Power", VerfBlog, Saturday 18 Apr 2020. Available at https://verfassungsblog.de/testing-the-limits-of-eu-healthemergency-power/.

\footnotetext{
${ }^{66}$ In this regard, see Editorial Comments, "Disease and recovery in (COVID-afflicted) Europe", Common Market Law Review, vol. 57, n. ${ }^{\circ}$ 3, 2020, pp. 619-630.
} 
ASHWORTH, G., "Heritage and Local Development: a reluctant relationship", in RIZZO, I. \& MIGNOSA, A. (eds), Handbook on the Economics of Cultural Heritage, Elgar, 2013, pp. $367-385$.

ATECA AMESTOY, V., "Demand for cultural heritage", in RIZZO, I. \& MIGNOSA, A. (eds), Handbook on the Economics of Cultural Heritage, Elgar, 2013, pp. 89 - 110.

AVI-YONAH, R., "COVID-19 and US Tax Policy: What Needs to Change?", Intertax, Vol. 48, núm., 8/9, 2020, pp. 790 - 793.

BÁEZ, A. \& PEDREIRA, J., "Spain”, in Taxation of charities: EATLP Annual Congress Rotterdam 31 May - 2 June 2012, IBDF, 2015, pp. 511 - 540.

BATER, P., HONDIUS, F. \& LIEBER, P.K., The Tax Treatment of NGOs, Kluwer, 2003.

BENHAMOU, F., "Public Intervention for Cultural Heritage: normative issues and tools", in RIZZO, I. \& MIGNOSA, A. (eds), Handbook on the Economics of Cultural Heritage, Elgar, 2013, pp. 3 - 16.

BENHAMOU, F., "Who owns cultural goods? The case of built heritage", in GINSBURGH, V.A. (ed), Economics of Art and Culture, Elsevier, 2003, pp. 187 - 202.

BERETTA, G., "L'imposta di soggiorno: amnesie legislative ed esigenze di riforma", Università Cattaneo working papers, núm 3., 2017.

BIZIOLI, G. \& BERETTA, G., "Italy's Tax and Fiscal Policy Measures at the Time of the COVID-19 Crisis: 'Tax Peanuts' Without a New Deal”, Intertax, Vol. 48, núm., 8/9, 2020, pp. $761-768$.

BONET, L., "Heritage Tourism", in RIZZO, I. \& MIGNOSA, A. (eds), Handbook on the Economics of Cultural Heritage, Elgar, 2013, pp. 386 - 401.

BOWLER-SMITH, M. et al. (eds.), Taxation of charities: EATLP Annual Congress Rotterdam 31 May - 2 June 2012, IBFD, 2015.

BROWN, J. \& HAY-EDIE, T., Engaging Local Communities in the Stewardship of World Heritage, UNESCO, 2014.

CASAS AGUDO, D., "Patrimonio histórico y extrafiscalidad en el ámbito de la Hacienda Municipal", Revista española de Derecho Financiero, núm., 172, 2016, pp. 131 - 176.

CHEN, W., HUA, J., "Citizens' distrust of government and their protest responses in a contingent valuation study of urban heritage trees in Guangzhou (China)", Journal of Environmental Management, núm., 155, 2015, pp. 40 - 48. 
COLliER, R., PIRLOT, A., VELLA, J., "COVID-19 and Fiscal Policies: Tax Policy and the COVID-19 Crisis”, Intertax, vol. 48, núm. 8/9., 2020, pp. 794 - 804.

CRAUFURD, R., "Art. 151 EC and European Identity", in CRAUFURD, R. Culture and European Union Law, Oxford University Press, 2004, pp. 278 - 297.

Editorial Comments, "Disease and recovery in (COVID-afflicted) Europe", Common Market Law Review, vol. 57, núm.,3, 2020, pp. 619 - 630.

GLIKSBERG, D., "General Report", in IFA, Cahiers de Droit Fiscal International, 53 ${ }^{\text {rd }}$ Congress of IFA, Kluwer, 1999.

GOTO, K., "Why do Governments Financially Support the Creative Industry", in HEMELS, S. \& GOTO, K. (ed.), Tax Incentives for the Creative Industry, Springer, 2017, pp. 21 -31 .

GRANAT, K., The Principle of Subsidiarity and its Enforcement in the EU Legal Order: The Role of National Parliaments in the Early Warning System, Hart Publishing, 2018.

HEIDENBAUER, S., Chariting Crossing Borders, Kluwer, 2011.

HEMELS, S., "Tax Incentives as a Creative Industries Policy Instrument”, in HEMELS, S. \& GOTO, K. (ed.), Tax Incentives for the Creative Industries, Springer, 2017, pp. 33 - 64.

HOLLER, M.J. \& I. MAZZA, I., "Cultural heritage: public decision-making and implementation" in RIZZO, I. \& MIGNOSA, A. (eds), Handbook on the Economics of Cultural Heritage, Elgar, 2013, pp. 17 - 36.

ICCROM, "People-Centred Approaches to the Conservation of Cultural Heritage: Living Heritage", 2015. Available at https://www.iccrom.org/sites/default/files/PCA_Annexe2.pdf.

IFA, Cahiers de Droit Fiscal International, 53 ${ }^{\text {rd }}$ Congress of IFA, Kluwer, 1999.

JOCHUM, H. \& LAMPERT, S., “Germany”, in Taxation of charities: EATLP Annual Congress Rotterdam 31 May - 2 June 2012, IBFD, 2015, pp. 281 - 300.

KOELE, I.A., International Taxation of Philanthropy, IBFD, 2007.

KOFLER, G., "EU power to tax: Competences in the area of direct taxation", in HJI PANAYI, C. (ed), Research Handbook on European Union Taxation Law, Elgar, 2020, pp. 11 50. 
LI, J., KRISHNAMURTHY, S., RODERS, A.P., VAN WESEMAELA, P., "Community participation in cultural heritage management: A systematic literature review comparing Chinese and international practices", Cities, Vol. 96, 2020, pp. 1 -9.

MASTELLONE, P., "International and EU Measures for the Protection of Cultural Heritage: Towards Broader Use of Tax Breaks to Stimulate Private Engagement', European Taxation, IBFD, Vol. 59, núm., 2/3, pp. 81 - 88.

MUCCIARIELLO, A., “Art bonus e crowdfunding”, in CORDEIRO GUERRA, R., PACE, A., VERRIGNI, C. and VIOTTO, A. (eds), Finanza pubblica e misure tributarie per il patrimonio culturale. Prime riflessioni, Giappichelli, 2019, pp. 265 - 280.

PEETERS, P. "A clear path towards sustainable mass tourism? Rejoinder to the paper 'Organic, incremental and induced paths to sustainable mass tourism convergence' by David B. WEAVER”, Tourism Management, Vol. 33, núm 5, 2012, pp. 1038 - 1041.

PETERS, M.A., "Philosophy and Pandemic in the Postdigital Era: Foucault, Agamben, Žižek", Postdigital Science and Education, Vol. 2, núm., 3, 2020, pp. 556 - 561.

PHILLIPS, R.G. and STEIN, J.M., “An Indicator Framework for Linking Historic Preservation and Community Economic Development”, Social Indicator Research, Vol. 113, núm 1, 2013, pp. 1-15.

REVELLI, F., "Tax Incentives for Cultural Heritage Conservation", in RIZZO, I. \& MIGNOSA, A. (eds), Handbook on the Economics of Cultural Heritage, Elgar, 2013, pp. $129-150$.

SEAMAN, B.A., "The role of the private sector in cultural heritage", in RIZZO, I. \& MIGNOSA, A. (eds), Handbook on the Economics of Cultural Heritage, Elgar, 2013, pp. $111-128$.

SITRIN, M. (ed), Pandemic Solidarity Mutual Aid during the Covid-19 Crisis, Pluto Press, 2020.

SUÁREZ-INCLÁN, M.R., "Financial Regulations and Tax Incentives with the Aim to Stimulate the Protection and Preservation of cultural Heritage in Spain", in HOFFMAN, B. (ed), Art and Cultural Heritage: law, policy and practice, Cambridge Univ. Press, 2006, pp. $455-460$.

THE COUNCIL OF EUROPE, Tax incentives for cultural Heritage Conservation, 13 November 2003, Report 9913, available at: https://assembly.coe.int/nw/xml/XRef/X2H-XrefViewHTML.asp?FileID=10311\&lang=en. 
THE COUNCIL OF EUROPE, The private management of cultural property, 24 October 2005, Report 10731, available at: http://assembly.coe.int/nw/xml/XRef/X2H-XrefViewHTML.asp?FileID=11062\&lang=.

VAN DENDER, K., O’REILLY, P., \& PERREN, S., “COVID-19 and Fiscal Policies: Tax and Fiscal Policy in Response to the Coronavirus Crisis: Strengthening Confidence and Resilience", Intertax, vol. 48, nº 8/9, 2020, pp. 736 - 742.

VAN WEEGHEL, S., “COVID-19 and Beyond”, Intertax, Vol. 48, núm, 8/9, 2020, pp. 733 735 .

VENTURA, C., CASSALIA, G. \& DELLA SPINA, L., "New models of Public-private Partnership in Cultural Heritage sector: Sponsorships between models and traps", Procedia Social and Behavioral Science, Vol. 223, 2016, pp. 257 - 264.

WEAVER, D.B., "Organic, incremental and induced paths to sustainable mass tourism convergence”, Tourism Management, Vol. 33, núm. 5, 2012, pp. 1030 - 1037.

ŽIŽEK, S., Pandemic!: COVID-19 Shakes the World, OR Book, 2020. 